\title{
EFEKTIVITAS DAN KINERJA TERHADAP PENGELOLAAN BADAN USAHA MILIK DESA LAGADING KECAMATAN PITU RIASE KABUPATEN SIDENRENG RAPPANG
}

\author{
Gusni \\ Fakultas IImu Sosial dan IImu Politik,Universitas Muhammadiyah Sidenreng Rappang \\ gusni43151047e1@gmailcom
}

\begin{abstract}
Abstrak
Tujuan penelitian ini yaitu Untuk mengetahui pengaruh efektivitas terhadap pengelolaan badan usaha milik Lagading Kecamatan Pitu Riase Kabupaten Sidenreng Rappang, Untuk Mengetahui pengaruh kinerja terhadap pengelolaan badan usaha milik desa Lagading Kecamatan Pitu Riase Kabupaten Sidenreng Rappang, Untuk mengetahui pengaruh efektivitas dan kinerja terhadap pengelolaan badan usaha milik desa dalam meningkatkan pendapatan asli desa di Lagading Kecamatan Pitu Riase Kabupaten Sidenreng Rappang.Populasi dalam penelitian ini adalah keseluruhan jumlah KK di Desa lagading yang berjumlah 396 yang terdiri dari 4 Dusun. Teknik pengambilan sampel menggunakan rumus Slovin dengan hasil 79,8 dibulatkan menjadi 80 responden, diambil berdasarkan teknik Probability sampling lebih tepatnya Random sampling. Tipe penelitian ini adalah Deskriptif Kuantitatif. Teknik pengumpulan data yang digunakan dalam penelitian ini adalah observasi, kuesioner, dokumentasi dan studi kepustakan. Data yang terkumpul selanjutnya dianalisis menggunakan teknik analisiss data dengan menggunakan skala likert, analisis regresi linear sederhana, kemudian di uji dengan uji Validitas, uji Reabilitas dengan menggunakan SPSS 16.0. Berdasarkan hasil penelitian dari variabel Berdasarkan hasil penelitian dari variabel Efektivitas (X1) didapatkan rata-rata persentase sebesar $57 \%$ termasuk dalam kategori "Cukup berpengaruh". Diukur melalui indikator Pendekatan sumber, Pendekatan proses, dan Pendekatan sasaran. Hasil penelitian dari variabel variabel kinerja (X2) didapatkan rata-rata persentase sebesar $57 \%$ termasuk dalam kategori "cukup berpengaruh". Diukur melalui indikator Produktivitas, Kualitas Layanan, Responsivitas, Responsibilitas dan Akuntabilitas. hasil penelitian dari variabel Pengelolaan BUMdes $(\mathrm{Y})$ didapatkan rata-rata persentase sebesar $54 \%$ termasuk dalam kategori "Cukup berpengaruh". Diukur melalui indikator Koperatif, Partisipatif, Emansipatif, Transparan, Akuntabel dan Sustainabel.
\end{abstract}

Kata Kunci : Efektivitas,Kinerja, dan Pengelolaan

\section{Abstract}

The purpose of this study is to determine the effect of effectiveness on the management of business entities owned by Lagading District of Pitu Riase, Sidenreng Rappang Regency, To determine the effect of performance on the management of business entities owned by the village of Lagading, District of Pitu Riase, District of Sidenreng Rappang, to determine the effect of effectiveness and performance on the management of business entities owned villages in increasing village original income in Lagading, Pitu Riase District, Sidenreng Rappang Regency. The population in this study is the overall number of households in the lagading village, amounting to 396 consisting of 4 hamlets. The sampling technique used the Slovin formula with the results of 79.8 rounded up to 80 respondents, taken based on the Probability sampling technique, more precisely Random sampling. This type of research is quantitative descriptive. Data collection techniques used in this study were observation, questionnaires, documentation and library research. The collected data is then analyzed using data analysis techniques using a Likert scale, a simple linear regression analysis, then tested with a validity test, a reliability test using SPSS 16.0. Based on the research results of the variables Based on the results of the study of the Effectiveness variable (X1) obtained an average percentage of $57 \%$ included in the category of "Enough influence". Measured through indicators The source approach, the process approach, and the target approach. The results of the study of the variable performance variables (X2) obtained an average percentage of $57 \%$ included in the category of "quite influential". Measured through indicators of Productivity, Service Quality, Responsiveness, Responsibility and Accountability. the 
results of research on the management variable BUMdes $(Y)$ obtained an average percentage of $54 \%$ included in the category of "Enough influence". Measured through indicators of Cooperative, Participatory, Emancipative, Transparent, Accountable and Sustainability.

Keywords: Effectiveness, Performance, and Management 


\section{A. PENDAHULUAN}

Kewenangan yang diberikan kepada daerah merupakan bentuk untuk mewujudkan Daerah yang mandiri dan mampu mengurus serta mengatur kebutuhan daerahnya.Kebijakan tersebut tidak hanya di berikan untuk daerah saja.Di era reformasi seperti saat ini, pemberian kewenangan otonomi lebih diarahkan pada tingkatan yang terendah dalam struktur pemerintahan yaitu Desa.Hal ini dilakukan untuk meningkatkan pembangunan di desa yang pada era otonomi daerah dapat mendukung pondasi daerah itu sendiri.

Wijaya (2012) bahwa otonomi desa didasarkan pada asal-usul dan adat istiadat setempat yang menghasilkan berbagai interaksi antar individu dalam masyarakat atau merupakan hasil cipta, rasa dan krasa masyarakat dalam kenyataannya pasti akan timbul keanekaragaman. Adanya otonomi desa juga untuk mengelola pendapatan asli desa yang berasal dari salah satunya hasil usaha seperti BUMDes, Alokasi Dana Desa (ADD) yaitu sebesar 30\% untuk belanja aparatur dan operasional pemerintah desa serta sebesar $70 \%$ untuk biaya pemberdayaan masyarakat hal tersebut sesuai dengan Permendagri Nomor 37 Tahun 2007 tentang pedoman pengelolaan keuangan desa. Upaya untuk cepat mengubah desa menjadi basis ekonomi jika tanpa diiringi mekanisme pengawasan maksimal dan tanggung jawab perangkat desa, dapat menjadi bumerang yang justru menghancurkan ikatan sosial warga.fragmentasi masyarakat sangat mungkin terjadi, ketika pemerintah desa menjadi sumber daya yang semakin menarik orang-orang untuk berebut jabatan. Untuk itu, perlu di siapkan sumber daya manusia dan peraturan pelaksanaannya secara matang, karena belum semua desa mempunyai kepala desa yang mempunyai kapasitas dan pemahaman yang sama soal alokasi dana desa tersebut, serta kemampuan menyusun rencana anggaran pendapatan dan belanja desa. Jumlah rupiah yang besar di desa akan rawan di korupsi kalau para pemangku kepentingan di pusat ataupun di daerah dan desa belum siap.
Ditegaskan dalam UU No. 06 tahun 2014 pasal 71 , keuangan desa adalah semua hak dan kewajiban desa yang dapat dinilai dengan uang serta segala sesuatu berupa uang dan barang yang berhubungan dengan pelaksanaan hak dan kewajiban tersebut menimbulkan pendapatan, belanja, pembiayaan, dan pengelolaan keuangan desa. Dan kepentingan masyarakat setempat dalam sistem pemerintahan negara kesatuan republik indonesia. "Adapun pemerintah Desa adalah Kepala Desa atau yang disebut dengan nama lain di bantu perat desa sebagai unsur penyelenggaraan pemerintahan desa (pasal 1 angka 3).

Bunyi pasal 33 ayat 3 UUD 1945 menyatakan bahwa "bumi dan air dan kekayaan alam yang terkandung di dalamnya dikuasai oleh negara dan dipergunakan untuk sebesar-besarnya kemakmuran rakyat" Maka dari itu pemerintah mengeluarkan Undang-undang tentang desa yaitu Undang-Undang No. 6 Tahun 2014. Dalam UU No. 6 Tahun 2014 menjelaskan bahwa pemerintah memberikan bantuan dalam bentuk dana desa. Dana desa ini tentunya memberikan angin segar bagi desa untuk bisa mengembangkan desa secara mandiri. Selain itu, peran pemerintah desa dalam mengalokasikan dana desa agar dapat memberikan kesejahteraan kepada masyarakat sangat penting.

Efektivitas adalah pemamfaatan sumber daya, sarana dan prasarana dalam jumlah tertentu yang di tetapkan sebelumnya untuk menghasilkan sejumlah barang dan jasa kegiatan yang dijalankannya Menurut Sagian (2001:24) Kinerja adalah tingkat pencapain hasil atas pelaksanaan tugas tertentu, sedangkankinerja perusahaan adalah tingkat pencapaian hasil dalam rangkain mewujudkan tujuan perusahaan (Simanjuntak 2005:1). Hadirnya BUMDes tentunya menjadi jawaban dari permasalahan yang ada di desa dan menjadi penggerak roda perekonomian desa. Badan Usaha Milik Desa (BUMDes) merupakan salah satu program prioritas Kementrian Desa, Pembangunan Daerah Tertinggal dan Transmigrasi (Kemendes PDTT) tahun 2017 dan bentuk 
implementasi dari Peraturan Menteri Desa, Pembangunan Daerah Tertinggal, Dan Transmigrasi Republik Indonesia Nomor 4 Tahun 2015 tentang Pendirian.

Pengurusan dan Pengelolaan dan Pembubaran Badan Usaha Milik Desa. Program BUMDes juga merupakan amanat dari Undang-undang Nomor 6 Tahun 2014 tentang desa, seperti disebutkan dalam pasal 87 ayat (1) bahwa "Desa dapat mendirikan Badan Usaha Milik Desa yang disebut BUM Desa". BUMDes juga merupakan hasil usaha yang termasuk dalam pendapatan asli desa yang tercantum dalam UndangUndang Nomor 6 Tahun 2014 Tentang Desa.

BUMDes (Badan Usaha Milik Desa) yaitu sebuah lembaga usaha Desa yang dikelola oleh pemerintah Desa dan masyarakat dengan maksud untuk memperkuat pereokonomian desa serta dibentuk sesuai dengan kebutuhan, kondisi ekonomi dan sosial budaya masyarakat.Kehadiran BUMDes harus mampu menampung, mengkosolidasi, dan mewadahi kegiatan usaha ekonomi desa.Usaha yang dipilih BUMDes juga tidak diperbolehkan mengancam kegiatan ekonomi masyarakat desa. Keberadaan BUMDesa antara lain untuk mewujudkan otonomi desa dan dapat meningkatkan Pendapatan Asli Desa. Berangkat dari salah satu tujuan dari pendirian BUMDesa, maka dapat mendorong pemerintah desa dalam merespon pendirian BUMDes.Keberadaan BUMDes tentunya menjadi harapan banyak elemen seperti pemerintah desa.Keberadaan BUMDes dapat menarik perhatian pemerintah desa karena dapat meningkatkan Pendapatan Asli desa.

Melihat dari tujuan pendirian BUMDes, tentunya keberhasilan BUMDes dilihat apabila keberadaan BUMDes bisa mencapai target atau sasaran yaitu memberikan sumbangan terhadap pendapatan Asli Desa.Pendapatan Asli Desa dapat berasal dari hasil usaha, hasil aset, swadaya dan partisipasi, gotong royong, dan lain-lain pendapatan Asli Desa. BUMDes dapat dikatakan dapat mencapai target atau sasaran tentunya perlu adanya kerjasama antar pemerintah desa dengan masyarakat. Partisipasi masyarakat dalam pembangunan nasional sangat diperlukan.Ketegasan dan Ketrampilan pemerintah dalam memberikan motivasi dan menggerakkan masyarakat untuk ikut serta dalam pengelolaan BUMDes demi terciptanya BUMDes yang berpengaruh sehingga target atau tujuan dari pendirian BUMDes dapat tercapai.

$$
\text { Badan Usaha Milik Desa }
$$

(BUMDES) Desa Lagading adalah lembaga usaha desa yang dikelola oleh masyarakat dan pemerintah desa dalam upaya memperkuat perekonomian desa, dan dibentuk berdasarkan kebutuhan serta potensi desa. Pedoman bagi daerah dan desa dalam pembentukan dan pengelolaan BUMDes yaitu Permendesa Nomor 4 Tahun 2015 tentang Pendirian, Pengurusan dan Pengelolaan, dan Pembubaran Badan Usaha Milik Desa. Pada tanggal 2 bulan desember 2014, Pemerintah Desa Lagading mendirikan BUMDes sebagai upaya pendayagunaan potensi desa dan diharapkan menjadi entitas yang mampu mengungkit perekonomian masyarakat. Sejak empat tahun ini pemerintah desa menjalankan BUMDes pada jenis Gas Elpiji, Pupuk dan Pamsimas yang jika dikelola secara optimal dapat menghasilkan manfaat pada wilayah ekonomi masyarakat dan desa.

Berdasarkan hasil observasi awal bahwa masalah yang terjadi yaitu masih ditemukan bahwa tidak lancarnya dan efektifnya pengelolaan BUMDes di Desa Lagading dan juga kinerja pemerintah desa tidak maksimal memberdayakan masyarakat untuk mengembangkan usaha-usaha yang sudah direncanakan seperti jenis usaha Pamsimas tidak berjalan dengan lancar karena mesin yang digunakan sudah tidak normal atau kurang memungkinkan, sehingga mengakibatkan kekurangan debit air yang dihasilkan, jadi masyarakat tidak banyak merasakan hasil dari pengelolaan usaha yang dilakukan oleh BUMDes. Peneliti melihat bahwa dalam upaya pengelolaan BUMDes pemerintah setempat juga kurang melibatkan masyarakat.Mestinya masyarakat mendapat tempat didalam pengelolaan BUMDes minimal peran 
masyarakat sebagai anggota BUMDes sehingga terjalin kerjasama yang baik anatara pemerintah dan masyarakat dalam meningkatkan pendapatan asli desa.

Fenomena diatas peneliti tertarik untuk meneliti tentang seberapa efektifkah keberadaan BUMDes dalam meningkatkan Pendapatan Asli Desa dengan mengambil judul Pengaruh Efektivitas dan KinerjaPengelolaan Badan Usaha Milik Desa Dalam Meningkatkan Pendapatan Asli Desa Lagading Kecamatan Pitu Riase Kabupaten Sidenreng Rappang dengan tujuan untuk mengetahuiseberapa besar Pengaruh Efektivitas Terhadap Pengelolaan Badan Usaha Milik Desa Lagading Kecamatan Pitu Riase Kabupaten Sidenreng Rappang, untuk Mengetahui seberapa besarPengaruh Kinerja Terhadap Pengelolaan Badan Usaha Milik Desa Lagading Kecamatan Pitu Riase Kabupaten Sidenreng Rappang, dan untuk mengetahui seberapa besar PengaruhEfektivitas Dan Kinerja Terhadap Pengelolaan Badan Usaha Milik Desa Dalam Meningkatkan Pendapatan Asli Desa Di Lagading Kecamatan Pitu Riase Kabupaten Sidenreng Rappang.

\section{Konsep Efektivitas}

Efektivitas berasal dari kata efektif, menurut Kamus Besar Bahasa Indonesia kata efektif mempunyai arti efek, pengaruh, akibat atau dapat membawa hasil. Menurut Kurniawan (2005) efektivitas adalah kemampuan melaksanakan tugas, fungsi (operasi kegiatan program atau misi) daripada suatu organisasi atau sejenisnya yang tidak adanya tekanan atau ketegangan diatara pelaksanaannya. Pengertian lain menurut Susanto, "Efektivitas merupakan daya pesan untuk mempengaruhi atau tingkat kemampuan pesan-pesan untuk mempengaruhi" (Susanto, 1975:156). Menurut pengertian Susanto diatas, efektivitas bisa diartikan sebagai suatu pengukuran akan tercapainya tujuan yang telah direncanakan sebelumnya secara matang.

\footnotetext{
Beberapa pendapat yang telah dikemukakan mengenai pengertian efektivitas, dapat ditarik kesimpulan bahwa efektivitas merupakan alat pengukur yang dapat menyatakan seberapa jauh target yang terlah dicapai, dimana target tersebut sudah
}

direncanakan terlebih dahulu. Target yang ditentukan dapat berupa kuantitas, kualitas, dan waktu. Menurut pendapat Mahmudi mendefinisikan efektivitas, sebagai berikut:"Efektivitas merupakan hubungan antara output dengan tujuan, semakin besar kontribusi (sumbangan) output terhadap pencapaian tujuan, maka semakin efektif organisasi, program atau kegiatan"(Mahmudi, 2005:92). Efektivitas berfokus pada outcome (hasil), program, atau kegiatan yang dinilai efektif apabila output yang dihasilkan dapat memenuhi tujuan yang diharapkan atau dikatakan spending wisely, Selain itu juga dalam mengukur efektivitas sebuah organisasi dapat dilakukan dengan tiga metode, seperti yang yang dikemukakan Masruri, M (2017), yakni:

a. Pendekatan Sumber (resource approach) menurut Masrusi (2017) adalah Pendekatan mengutamakan adanya keberhasilan organisasi untuk memperoleh sumber daya, berpengaruh fisik maupun nonfisik yang sesuai dengan kebutuhan organisasi.

b. Pendekatan proses (process approach)menurut Masrusi (2017) adalah untuk melihat sejauh mana efektivitas pelaksanaan program dari semua kegiatan proses internal atau mekanisme organisasi.

c. Pendekatan sasaran (goals approach) menurut Masrusi (2017) dimana pusat perhatian pada output, mengukur keberhasilan organisasi untuk mencapai hasil (output) yang sesuai dengan rencana

\section{Konsep Kinerja}

Pencapaian sasaran dan tujuan instansi, organisasi disusun dalamunit-unit kerja yang lebih kecil, dengan pembagian kerja, sistem kerja dan mekanisme kerja yang jelas. Sebagai ilustrasi, misi dan tugas pokok satu departemen pemerintahan dibagi habis kedalam tugas pokok beberapa direktorat jendral. tugas pokok setiap direktorat jenderal dibagi habis menjadi tugas pokok beberapa direktorat, dan selanjutnya masing-masing dibagi habis oleh beberapa sub direktorat, kemudian beberapa seksi, dantugas pokok setiap seksi dilakukan oleh beberapa orang pegawai. setiap orang dalam satu unit kerja mempunyai sasaran dan uraian tugas tertentu, sebagai bagian dari sasaran unit kerja dimaksud. Kinerja adalah 
tingkat pencapain hasil atas pelaksanaan tugas tertentu, sedangkankinerja perusahaan adalah tingkat pencapaian hasil dalm rangkain mewujutkan tujuanperusahaan (Simanjuntak 2005:1). Dalam rangka pencapain sasaran dan tujuanperusahaan, organisasi disusun dalam unit-unit kerja yang lebih kecil dengan pembagiankerja, sistem kerja, dan mekanisme kerja yang jelas. Verhthrivai (2006:309) menyatakan bahwa kinerja merupakan prilaku yang nyatayang ditampilakan setiap orang sebagai prestasi kerja yang dihasikan oleh karyawan yangsesuai dengan perananya pada sebuah instansi.

Fadel Muhammad dalam Husain, (2011 : 104) mengemukakan kinerja birokrasi pemerintah terdiri atas dua komponen yaitu kinerja aksi dan kinerja hasil, keterlibatanmental emosional masyarakat dari seni peningkatan kinerja birokrasi adalah nampak padaperumusan kineja aksi dan kinerja hasil dari setiap lingkup pemerintah desa dankelurahan. Agus Dwiyanto (2005: 9) mengemukakan beberapa indikator yang dapat digunakan dalam mengukur kinerja birokrasi publik, yaitu :
a. Produktivitas
b. Kualitas Layanan.
c. Responsivitas.
d. Responsibilitas.
e. Akuntabilitas

\section{Pengelolaan badan usaha milik desa}

Secara umum pengelolaan adalah kegiatan merubah sesuatu hingga menjadi berpengaruh, serta memiliki nilai-nilai yang lebih tinggi dari semula juga dapat diarahkan pembinaan yaitu usaha melakukan sesuatu agar lebih sesuai serta cocok dengan kebutuhan sehingga lebih bermamfaat. Menurut S. Pamuji (2012 : 12) mengutamakan pengertian pengelolaan sebagai berikut: "Perkataan pengelolaan berasal dari kata kelola yang berarti sama dengan mengurus jadi pengelolaan diartikan sebagai pengurusan, yaitu merubah sesuatu hingga menjadi baru yang memiliki nilai-nilai yang lebih tinggi. Dengan demikian pengelolaan juga mengandung makna sebagai pembaharuan, yaitu melakukan usaha-usaha untuk membuat sesuatu menjadi lebih sesuai atau cocok dengan kebutuhan menjadi lebih berpengaruh dan bermamfaat" Badan Usaha Milik Desa merupakan lembaga usaha ekonomi desa yang dikelola oleh masyarakat dan pemerntahan desa dalam upaya membangun desa dengan memperkuat perekonomian desa. Menurut Undang-Undang Nomor 6 Tahun 2014 Badan Usaha Milik Desa adalah badan usaha yang seluruh atau sebagian besar modalnya dimiliki oleh Desa melalui penyertaan secara langsung yang berasal dari kekayaan desa yang dipisahkan guna mengelola aset, jasa pelayanan, dan usaha lainnya untuk sebesar besarnya kesejahteraan masyarakat desa. Tujuan dari dibentuknya Badan Usaha Milik Desa dalam (PKDSP, 2007)adalah :

a. Meningkatkan perekonomian desa.

b. Meningkatkan pendapatan asli desa.

c. Meningkatkan pengolahan potensi desa sesuai dengan kebutuhan masyarakat.

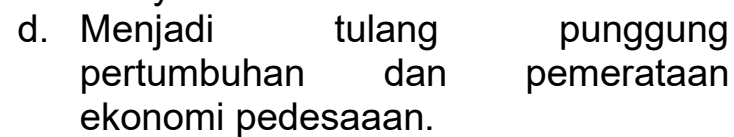

\section{Pemerintah Desa}

Pemerintahan desa menurut A. W Wijaya (2012), merupakan subsistem dari sistem penyelenggaraan Pemerintah, sehingga Desa memiliki kewenangan untuk mengatur dan mengurus kepentingan masyarakatnya.KepalaDesa

bertanggungjawab kepada Badan Permusyawaratan Desa dan menyampaikan laporan pelaksanaan tersebut kepada Bupati. Sumber Pendapatan desa terdiridari

\section{a. Pendapatan Asli Desa (PADesa);}

Pendapatan Asli Desa menurut Undangundang Nomor 6 tahun 2014 Pasal 72 Ayat (1), bahwa pendapatan asli desa merupakan pendapatan yang berasal dari kewenangan desa berdasarkan hak asal usul dan kewenangan skala lokal desa.

b. Bagi Hasil Pajak/Retribusi Kabupaten/Kota.Besar pembagian hasil pajak Kabupaten/Kota paling sedikit $10 \%$ untuk desa sedangkan untuk bagi hasil retribusi Kabupaten/Kota diperuntukkan untuk desa.

c. Alokasi Dana Desa (ADD).Pendapatan desa tidak berasal dari Pendapatan Asli Desa (PADes) saja tetapi juga berasal dari Alokasi Dana Desa (ADD). Alokasi Dana Desa berasal dari APBD. Alokasi Dana Desa (ADD) bahwa Alokasi Dana Desa (ADD) yaitu sebesar $30 \%$ untuk belanja 
aparatur dan operasional pemerintah desa serta sebesar $70 \%$ untuk biaya pemberdayaan masyarakat hal tersebut sesuai dengan Permendagri Nomor 37 Tahun 2007 tentang pedoman pengelolaan keuangan desa.

\section{B. METODE PENELITIAN}

Sebagai objek penelitian dalam memperoleh data dan informasi, maka penulis mengadakan penelitian di Desa LagadingKecamatanPituRiaseKabupatenSid enrengRappang pada bulan juli sampai dengan agustus atau 2 Bulan lamanya. Pemilihan lokasi sesuai dengan yang lokasi masalah yang terjadi. Jenis penelitian ini adalah penelitian deskriptif yang bertujuan untuk mendapatkan dan menyampaikan fakta-fakta dengan jelas dan teliti. Pada penelitian ini, peneliti hanya mengembangkan konsep dan menghimpun fakta tetapi tidak melakukan pengujian hipotesis. Menurut Sugiyono (2014: 38) varibel penelitian adalah segala sesuatu yang berbentuk apa saja yang ditetapkan oleh peneliti untuk dipelajari sehingga diperoleh informasi tentang hal tersebut.

Populasi dalam penilitian ini sebanyak 396 kartu keluarga (berdasarkan data profil Desa Lagading Tahun 2019) sedangkan teknik penarikan sampel yang digunakan adalah sampel acak dengan tingkat kesalahan $10 \%$, jadi total sampel dalam hal ini berjumlah 80 Kepala Keluarga. Teknik pengumpulan data yang digunakan yaitu, Observasi, Kuisioner (angket), Studi kepustakaan, dan Dokumentasi dengan teknik analisis data yaitu uji validitas, uji realibilitas dan tabulasi frekuensi

\section{HASIL DAN PEMBAHASAN}

1. Rekapitulasi indikator efektivitas atau variabel X1

Hasil rata-rata persentase dari 3 item pertanyaan pada indikator efektivitas (Variabel X1) di atas, maka didapatkan hasil rata-rata persentase yaitu $57 \%$, jadi dapat ditarik suatu kesimpulan bahwa pada indikator ini berada pada kategori "cukup Berpengaruh".

2. Rekapitulasi indikator kinerja atau variabel $\mathrm{X} 2$

Hasil rata-rata persentase dari 5 item pertanyaan pada indikator kinerja
(Variabel X2) di atas, maka didapatkan hasil rata-rata persentase yaitu $57 \%$, jadi dapat ditarik suatu kesimpulan bahwa pada indikator ini berada pada kategori "cukup Berpengaruh".

3. Rekapitulasi indikator Pengelolaan BUMdes atau variabel $Y$

Rata-rata persentase dari 6 item pertanyaan pada indikator Pengelolaan BUMdes (Variabel Y) di atas, maka didapatkan hasil rata-rata persentase yaitu $54 \%$, jadi dapat ditarik suatu kesimpulan bahwa pada indikator ini berada pada kategori "cukup Berpengaruh".

Keofisien determinasi $\left(R^{2}\right)$ digunakan untuk mengetahui pengaruh $X$ terhadap $Y$ dalam menerengkan variasi variabel dependen berdasarkan tabel model Summary, koeisien determinasi berganda $\left(R^{2}\right)$ atau $R$ square $=0,232$ berarti secara bersama-sama $23 \%$ perubahan variabel Pengelolaan Bumdes $(Y)$ dapat dijelaskan oleh variabel Efektivitas dan kinerja (X), atau dengan kata lain pengaruh variabel bebas terhadap variabel terikat sebesar $23 \%$ sedangkan sisanya $77 \%$ dipengaruhi oleh variabel lain yang tidak masuk dalam kerangka konsep penelitian ini.

1. Efektivitas

a. Pendekatan Sumber. Hasil penelitian pada indikator pendekatan sumber diperoleh persentase sebesar $54 \%$ dari $100 \%$ yang diharapkan. Hal ini disebabkan oleh jumlah sumber daya manusia dan juga kemampuan SDM dalam pengelolaan BUMDes. Jumlah sumber daya manusia tentu akan mempengaruhi pengelolaan BUMDes. BUMDes Desa Lagading yang hanya dikelola oleh beberapa orang saja akan berbeda hasilnya jika dikelola oleh lebih banyak orang. Kemampuan pengelola juga menjadi perhatian tersendiri, Beberapa pegawai BUMDes juga kurang dalam hal kemampuan manajerial bisa dilihat dari tingkat pendidikan pengelola BUMDes itu sendiri, hal ini tentu saja perlu mendapat perhatian lebih dimana dalam mengelola BUMDes tentu saja diperlukan tenaga kerja yang ahli. Oleh karena itu untuk meningkatkan kualitas tenaga kerja dilakukan pendidikan maupun pelatihan tertentu. 
b. Pendekatan Proses. Pengelolaan BUMDes tentu saja ada beberapa program yang diutamakan,khusus desa lagading yang digunakan adalah pengelolaan BUMDes berbasis gas elpiji, pupuk dan penyaluran air bersih. Dari hasil penelitian pada indikator pendekatan proses diperoleh persentase sebesar $56 \%$ dari 100\% yang diharapkan, hal ini disebabkan oleh pemanfaatan sumber daya dalam pengelolaan BUMDes belum maksimal.

c. Pendekatan sasaran. Hasil penelitian pada indikator pendekatan sasaran diperoleh persentase sebesar $61 \%$ dari $100 \%$ yang diharapkan.Untuk dapat mengukur keberhasilan suatu program dapat dilihat dari seberapa jauh program itu mencapai tujuannya. Dimana dalam penelitian ini yang dimaksud pencapaian tujuan adalah keseluruhan upaya pencapaian tujuan harus dipandang sebagai suatu proses. Oleh karena itu, agar pencapaian tujuan akhir semakin terjamin, diperlukan pentahapan, baik dalam arti pentahapan pencapaian bagianbagiannya maupun pentahapan dalam arti periodesasinya.

2. Kinerja

a. Produktivitas. Produktivitas berkaitan dengan peningkatan kesejahteraan masyarakat. BUMDes desa lagading dalam meningkatkan kesejahteraan massyarakat melkasanakan program pada bagian pendistribusian gas elpiji pupuk dan PANSIMAS. Dari hasil penelitian pada indikator produktivitas diperoleh persentase sebesar $56 \%$ dari $100 \%$ yang diharapkan. Hasil lain dari $100 \%$ yang diharapkan dipengaruhi oleh jumlah pegawai BUMDes desa lagading. Keterbatasan jumlah pegawai akan mempengaruhi program yang dilaksanakan.

b. Kualitas layana. Terkhusus dengan kepuasan masyarakat, dengan adanya beberapa program yang telah dijalankan oleh BUMDes sedikit banyaknya akan berdampak kepada masyarakat. Dari hasil penelitian pada indikator kualitas layanan diperoleh persentase sebesar $58 \%$ dari 100\% yang diharapkan. Kulitas layanan bergantung dari kemampuan pegawai dalam menjalankan program.semakin baik kemampuan pegawai maka semakin baik pula program yang dijalankan.

c. Responsivitas. Hal tersebut jelas menunjukkan kegagalan organisasi dalam mewujudkan misi dan tujuan organisasi. Dari hasil penelitian pada indikator responsivitas diperoleh persentase sebesar $54 \%$ dari 100\% yang diharapkan. Program yang dijalankan di BUMDes desa lagading sudah sesuai dengan kebutuhan masyarakat. Gas elpiji dan pupuk untuk masyarakat petani. Namun untuk gas elpiji sendiri masih sering kekurangan stock karena gas elpiji tidak hanya digunakan sebagai alat rumah tangga saja tapi juga di gunakan sebagai tenaga mesin pompa pada pertanian masyarakat.

d. Responsibilitas. Responsibilitas menjelaskan apakah pelaksanaan kegiatan organisasi publik itu dilakukan sesuai dengan prinsip-prinsip administrasi yang benar atau sesuai dengan kebijakan organisasi, berpengaruh yang eksplisit maupun implisit (Lenvine, 1990). Oleh sebab itu, responsibilitas bisa saja pada suatu ketika berbenturan dengan responsivitas. Dari hasil penelitian pada indikator respon sibiltas diperoleh persentase sebesar $56 \%$ dari $100 \%$ yang diharapkan.

e. Akuntabilitas. Hasil penelitian pada indikator pendekatan sumber diperoleh persentase sebesar $63 \%$ dari 100\% yang diharapkan. Dalam pelaksanaan program BUMDes desa lagading sering mengalami masalah pada pendistribusian pupuk, distribusi pupuk yang tidak merata terkadang menyebabkan ketidakpuasan masyarakat. Pendistribusian pupuk terkadang lebih didominasi oleh petani yang juga merupakan orang penting di desa atau oleh oranag yang memiliki kedekatan personal dengan pihak pengelola BUMDes.

3. Pengelolaan BUMDES
a. Kooperatif. Hasil penelitian pada indikator kooperatifdiperoleh 
persentase sebesar $54 \%$ dari $100 \%$ yang diharapkan. Hal ini diakibatkan karena kurangnya kerjasama dari pihak pengelola BUMDes dengan pihak lain. Satu satunya pihak yang terjalin kerjasama dengan BUMDes adalah pihak pemerintah desa itu sendiri.

b. Partisifatif. Pengelolaan semua komponen yang ada pada BUMDes harus mampu memberikan dukungan dan kontribusinya untuk mendorong kemajuan BUMDes. Dari hasil penelitian pada indikator partisipatif diperoleh persentase sebesar $54 \%$ dari $100 \%$ yang diharapkan. Kurangnya kerjasama mengakibatkan juga berkurangnya dukungan. Satu-satunya dukungan yang didapatkan hanya mengandalkan pemrintah desa. Sehingga bantuan maupun dana yang didapatkan terbatas.

c. Emansifatif. Mendapat perlakuan yang sama tanpa memandang golongan, suku, dan agama antar komponen pengelola BUMDes. Dari hasil penelitian pada indikator emansipatif diperoleh persentase sebesar $54 \%$ dari $100 \%$ yang diharapkan. Tekah dibahasakan sebelumnya bahwa terjadi beberapa kendala pada pendistribusian pupuk yang tidak merata pendistribusian pupuk terkadang lebih banyak kepada golongan tertentu, dalam hal ini golongan atau kelompok yang dekat dengan kelompok penguasa.

d. Transparan. Semua kegiatan usaha harus dapat diketahui oleh masyarkat dengan mudah dan terbuka. Dari hasil penelitian pada indikator transparan diperoleh persentase sebesar $53 \%$ dari $100 \%$ yang diharapkan.semua kegiatan usaha BUMDes desa lagading sudah diketahui oleh masyarakat secara umum namun hanya saja masyarakat tidak pernah tahu dengan penggunaan rincian anggaran dana pengelolaan BUMDes secara terbuka.

e. Akuntabel. Semua aktivitas usaha harus dapat dipertanggungjawabkan secara teknis maupun administratif. Dari hasil penelitian pada indikator pendekatan sumber diperoleh persentase sebesar $53 \%$ dari $100 \%$ yang diharapkan. dari beberapa kegiatan yang dialaksanakan oleh BUMDes semua kegiatan sudah terlaksana secara teknis namun secara adamistratif terkadang tidak sesuai dengan kondisi teknisnya.

f. Sustainabel. Semua kegiatan usaha dapat dikembangkan dan bersifat berkelanjutan yang dilaukan oleh masyarakat melalui BUMDes. Dari hasil penelitian pada indikator sustainabel diperoleh persentase sebesar $57 \%$ dari $100 \%$ yang diharapkan. pengembangan usaha tidak berjalan sebagaimana mestinya, buktinya pada pelaksanaan program penyediaan air bersih, mesin pompa sudah tidak layak pakai namun masih tetap digunakan.

\section{KESIMPULAN}

Berdasarkan pada pembahasan yang ada diatas maka hal ini dapat disimpulkan sebagai berikut:

1. Berdasarkan hasil penelitian dari variabel Efektivitas (X1) didapatkan rata-rata persentase sebesar $57 \%$ termasuk dalam kategori "Cukup berpengaruh". Diukur melalui indikator Pendekatan sumber $54 \%$, Pendekatan proses $57 \%$, dan Pendekatan sasaran $61 \%$.

2. Berdasarkan hasil penelitian dari variabel kinerja (X2) didapatkan ratarata persentase sebesar $57 \%$ termasuk dalam kategori "cukup berpengaruh". Diukur melalui indikator Produktivitas $56 \%$, Kualitas Layanan 58\%, Responsivitas 54\%, Responsibilitas $56 \%$ dan Akuntabilitas 63\%.

3. Berdasarkan dari hasil olah kuesioner dengan menggunakan SPSS versi 16.0 maka di ketahui dari tabel model summary bahwa Efektivitas dan kinerja memiliki pengaruh sebesar 23\% terhadapPengelolaan Badan Usaha Milik Desa Dalam Meningkatkan Pendapatan Asli Desa Lagading 
Kecamatan Pitu Riase Kabupaten Sidenreng Rappang.

\section{E. REFERENSI}

Ahmad, J. (2015). Metode Penelitian Administrasi Publik Teori dan Aplikasi. Yogyakarta, Gava Media.

Arikunto, Suharsimi. 2010. Prosedur Penelitian Suatu Pendekatan Praktik. Jakarta: Rineka Cipta.

Dwiyanto, Agus. 2012.Reformasi Birokrasi Publik, Yogyakarta: Gadjah Mada University Press.

Herdianyah, H. (2015). Metodelogi Penelitian Kualitatif Untuk IImu-IImu Sosial. Jakarta Selatan. Salemba Humanika.

Mangkunegara, Anwar Prabu. 2006.Evaluasi Kinerja SDM, Bandung: Refika Aditama.

Nurcholis, H. (2011). Pertumbuhan dan Penyelenggaraan Pemerintah Desa. Jakarta, Erlangga. 